\title{
Effect of Lamination Constitution on Buckling of Composite Laminated Cylindrical Shells under Torsion
}

\author{
○学 河合 啓太郎 （東海大院） 大野 雅士 （東海大） \\ 正粕谷平和 (東海大)
}

Keitarou KAWAI, Masashi ONO,

Tokai University, 1117, Kitakaname, Hiratsuka-shi, Kanagawa

Hirakazu KASUYA,

Tokai University

Tokai University

Key Words : Structural Analysis, Composite Materials, Laminated Cylindrical Shells, Buckling Strength, Torsion, Lamination Constitution

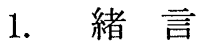

炭素絨維からなる高性能緎維強化プラスチック(CFRP) 材は, 比強度, 比剛性が高く, 円筒款構造としても航空宇宙分 野をはじめ, 幅広い分野の構造に数多く用いられている. このような異方性材料よりなる複合材料積層円筒殼は, カップリング効果などの各種積層構成効果があり，均質な 直交異方性円筒款とは異なる力学的挙動を示す。そこで, 各種外力が作用する複合材料積層円筒款の座屈現象を的 確に把握しておく必要が生じ, 数例の解析的研究の報告が なされている(1),(2).

本報告では，複合材料積層円筒款にねじりモーメントを 加えた場合について近似的に理論解析し, 積層順序, 積層 数, 積層角, 款の形状寸法などがねじり座屈值に及ぼす影 響を検討する。

\section{2. 理論的解析法}

解析モデルとして Fig.1 に示すような半径 $R$, 筒長 $L$, 板厚 $h$ の積層円筒款が両端にねじりモーメント $M$ ，を受け る場合を考え, 円筒軸方向, 円周方向, 半径方向にそれぞ れ $x, y, z$ 軸をとり, 座屈に伴う付加的変位成分を $u, v, w$ とする. 本報告では, 積層円筒款の座屈值の算出 理論式を，比較的広範囲な円筒殻形状に適応できる Flügge の款理論(3)を用いる. 合态力成分 $N_{x}, N_{y}, N_{x y}, N_{y x}$ と合飞 一メント成分 $M_{x}, M_{y}, M_{x y}, M_{y x}$ と中央面のひずみ成分 $\varepsilon_{x}, \varepsilon_{y}, \gamma_{x y}$, 曲率変化成分 $\kappa_{x}, \kappa_{y}, \kappa_{x y}$ の関係を表す構成方 程式は，カップリング項を考慮すると次式になる. 式中の $A_{i j}, B_{i j}, D_{i j}(i, j=1,2,6)$ はそれぞれ, 伸張剛性項, カッ プリング剛性項, 曲げ剛性項であり, 一方向強化材の繊維 方向, 繊維に直角方向の弾性係数 $E_{L}, E_{T}$, ポアソン比 $v_{L}, v_{T}$ およびせん断弾性係数 $G_{L T}$ などが与えられ, 積層順 序, 積層数, 積層角などが指定されると求められる。

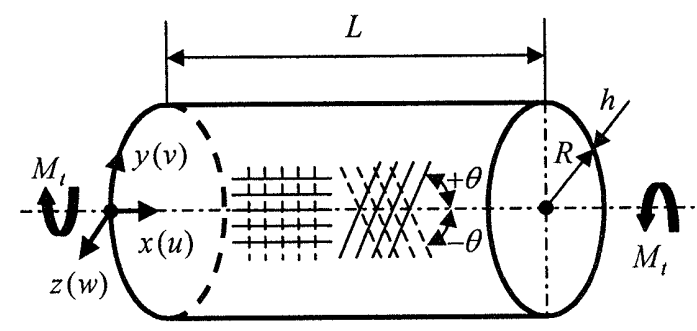

Fig.1 Configuration and coordinates of composite laminated cylindrical shell.

$$
\left.\begin{array}{rl}
\left\{\begin{array}{c}
N_{x} \\
N_{y} \\
N_{x y} \\
N_{y x}
\end{array}\right\}=\left[\begin{array}{ccc}
A_{11}+\frac{B_{11}}{R} & A_{12}+\frac{B_{12}}{R}+ & A_{16}+\frac{B_{16}}{R}+\frac{D_{16}}{2 R^{2}} \\
A_{12} & A_{22} & A_{26}+\frac{D_{26}}{2 R^{2}} \\
A_{16}+\frac{B_{16}}{R} & A_{26}+\frac{B_{26}}{R} & A_{66}+\frac{B_{66}}{R}+\frac{D_{66}}{2 R^{2}} \\
A_{16} & A_{26} & A_{66}+\frac{D_{66}}{2 R^{2}}
\end{array}\right]\left\{\begin{array}{l}
\varepsilon_{x} \\
\varepsilon_{y}
\end{array}\right\} \\
+\left[\begin{array}{ccc}
B_{11}+\frac{D_{11}}{R} & B_{12} & B_{16}+\frac{D_{16}}{2 R} \\
B_{12} & B_{22}-\frac{D_{22}}{R} & B_{26}-\frac{D_{26}}{2 R} \\
B_{16}+\frac{D_{16}}{R} & B_{26} & B_{66}+\frac{D_{66}}{2 R} \\
B_{16} & B_{26}-\frac{D_{26}}{R} & B_{66}-\frac{D_{66}}{2 R}
\end{array}\right]\left\{\kappa_{x}\right. \\
\kappa_{y} \\
\kappa_{x y}
\end{array}\right\}
$$

$$
\begin{aligned}
& \left\{\begin{array}{l}
M_{x} \\
M_{y} \\
M_{x y} \\
M_{y x}
\end{array}\right\}=\left[\begin{array}{ccc}
B_{11}+\frac{D_{11}}{R} & B_{12}+\frac{D_{12}}{R} & B_{16}+\frac{D_{16}}{R} \\
B_{12} & B_{22} & B_{26} \\
B_{16}+\frac{D_{16}}{R} & B_{26}+\frac{D_{26}}{R} & B_{66}+\frac{D_{66}}{R} \\
B_{16} & B_{26} & B_{66}
\end{array}\right]\left\{\begin{array}{c}
\varepsilon_{x} \\
\varepsilon_{y} \\
\gamma_{x y}
\end{array}\right\} \\
& +\left[\begin{array}{lll}
D_{11} & D_{12} & D_{16} \\
D_{12} & D_{22} & D_{26} \\
D_{16} & D_{26} & D_{66} \\
D_{16} & D_{26} & D_{66}
\end{array}\right]\left\{\begin{array}{l}
\kappa_{x} \\
\kappa_{y} \\
\kappa_{x y}
\end{array}\right\}
\end{aligned}
$$

一般的な積層円筒壳がねじりモーメント $M$ ，を受けると きの平衡方程式に，式(1)，(2) と座屈時のたわみ波形を代 入すると, 積層円筒殻の座屈值は次の係数行列式から固有 值として得られる。

$$
\left|\begin{array}{ccc}
H_{11}-2 \lambda n \tau_{t} h & H_{12} & H_{13} \\
H_{12} & H_{22}-2 \lambda n \tau_{t} h & H_{23}-2 \lambda \tau_{t} h \\
H_{13} & H_{23}-2 \lambda \tau_{t} h & H_{33}-2 \lambda n \tau_{t} h
\end{array}\right|=0
$$

ここで $\tau_{t}\left(=M_{t} / 2 \pi h R^{2}\right)$ はねじり応力である. $\lambda(=m \pi R / L)$ は軸方向半波長であり, $m$ は軸方向半波数, $n$ は円周方向 波数である. $H_{i j}(i, j=1,2,3)$ は, 各種剛性項と殼の形状 寸法によって決まる.

式(3)において軸方向半波数 $m$, 円周方向波数 $n$ を変化 させることによって得られるねじり応力 $\tau_{t}$ の最小值 $\bar{\tau}_{t}$ が 放じり座屈值となる。座屈值を無次元座屈係数 $K_{t}\left(=\bar{\tau}_{t} R / E_{T} h\right)$ のように表すと, 材料定数と積層構成が与 えられることにより, 款の形状パラメータ $Z\left(=L^{2} / R h\right)$, 積 層角 $\theta$ の関数として与えられる. 


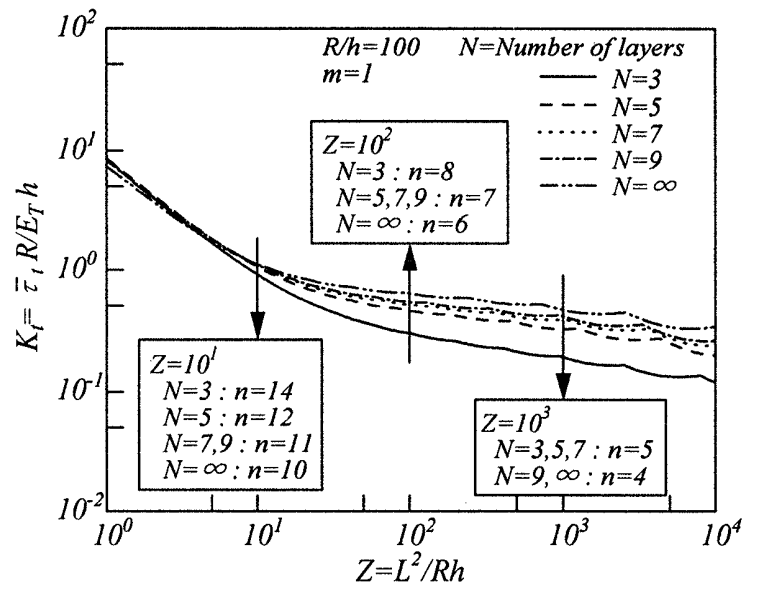

(a) Inner lamination angle $\theta=0$ (deg.)

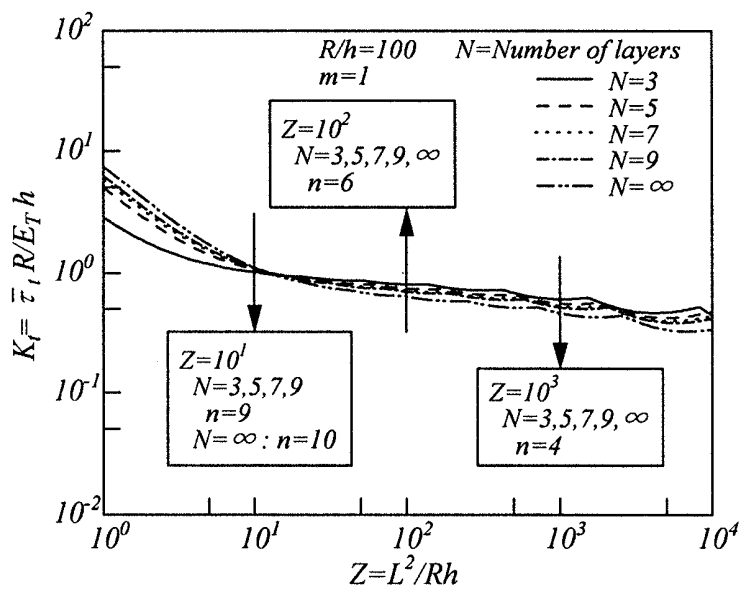

(b) Inner lamination angle $\theta=90$ (deg.)

Fig.2 Variation of buckling coefficients of symmetric cross - ply laminated cylindrical shells with shape parameter $Z$.

\section{3. 数値計算例と解析結果の検討}

数值計算例としては, 繊維容積含有率 $V_{f}=60 \%$ の炭素 緎維強化プラスチック(CFRP)材を考える(4).

クロスプライ積層円筒殻の数值計算結果を, 対称積層で, 最内層積層角が 0 (deg.) とした場合を Fig.2 (a)に，最内層積 層角が 90(deg.)を(b)に示す.

無次元座屈係数 $K$, と形状パラメータ $Z$ との関係は，対 称積層, 逆対称積層の場合ともに, $Z$ の増加に伴い $K_{t}$ 値 は低下する。

積層数 $N$ の影響は，対称積層で最内層積層角が $0(\mathrm{deg}$.) の場合には積層数の減少による $K_{t}$ 值の低下が顕著になり， $Z$ の增加に伴いその差は大きくなる．また最内層積層角が 90(deg.)の場合には積層数の減少に伴い， $K$ ，值は増加する. このように対称積層では，最内層積層角を $0(\mathrm{deg}$.$) とした場$ 合と 90(deg.)とした場合とでは，積層順序が $K_{t}$ 值に及ぼす 影響は顕著になってくる，逆対称積層の場合には，カップ リング効果が現れ， $K$ ，值は積層数が少ないと低下する.

アングルプライ積層円筒款の数值計算結果を, 対称積層 の場合を Fig.3 (a)に，逆対称積層の場合を(b)に示す，座屈 值に及ぼす形状パラメータ $Z$ の影響は, クロスプライ積層 円筒款の場合と同様に表されるので，一例として $R / h=100, Z=900$ の場合について示している.

積層角 $\theta$ の変化による $K$ 值は, 極めて積層数が少な い場合を除き，対称積層，逆対称積層の場合ともに $\theta$ の増加にともない変化し, 積層角が $0(\mathrm{deg}$.$) のとき最小$

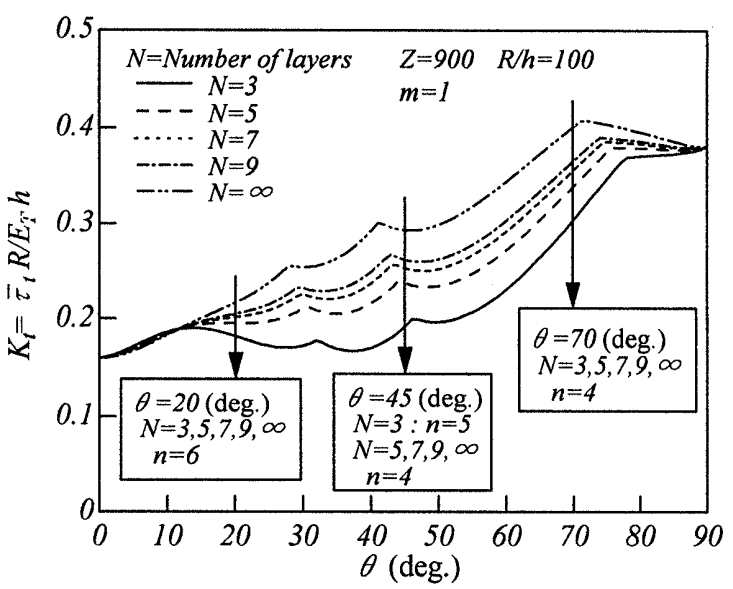

(a) Symmetric laminate

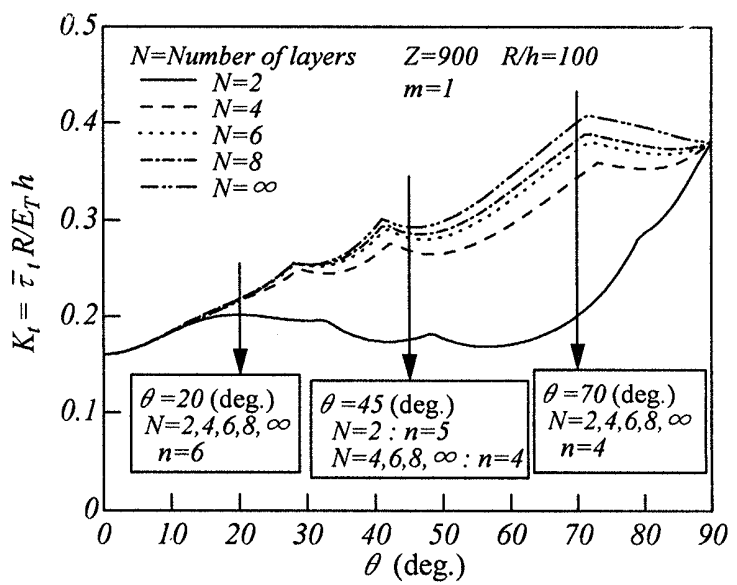

(b) Antisymmetric laminate

Fig.3 Variation of buckling coefficients of angle - ply laminated cylindrical shells with lamination angle $\theta$.

值を，70(deg.)近傍のとき最大值を示している.

積層数 $N$ の変化による $K_{t}$ 值の影響は積層角 0 (deg.), 90 (deg.) の場合には無関係であるが，その中間の積層角 0 (deg.) $<\theta<90$ (deg.) では，カップリング効果が現れ， 積層数が減少すると $K_{1}$ 值も減少する.

座屈波数のうち軸方向半波数 $m$ は, クロスプライ, アン グルプライ積層円筒殼の場合ともに, 形状パラメータ, 積 層数, 積層角に無関係で 1 であり, 円周方向波数 $n$ は形状 パラメータ, 積層数, 積層角の増加により減少を示す.

\section{4. 結 言}

本報告では，ねじりモーメントを受ける複合材料積層円 筒殻の座屈について, Flügge の款理論により座屈值を解析 し，代表的な CFRPについて，形状パラメータ $Z$, 積層角 $\theta$ に対して無次元座屈係数 $K_{t}$ で表示した。特に座屈特性 に及ぼす積層構成の影響を調べ, 積層順序, 積層数, 積層 角, 殼の形状寸法などの変化が座屈值に大きく影響するこ とを示した。

\section{文 献}

(1) R.M.Jones, Mechanics of Composite Materials,

Mc Graw-Hill, New York (1975)

(2) 粕谷平和, 日本複合材料学会誌, 17-2(1991), 74.

(3) W.Flügge, Stresses in Shells, Splinger-Verlag, Berlin (1962).

(4) 植村益次· 山田直樹, 材料, 24-257(1975), 156. 